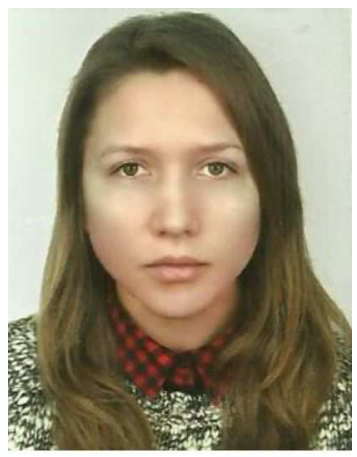

Natalia Hrunyk, Junior Researcher, Email: rgoutmollab@ukr.net

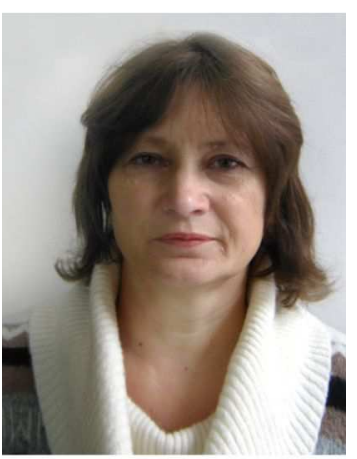

Valentyna Kovaleva, Senior Researcher, Email: rgoutmollab@ukr.net

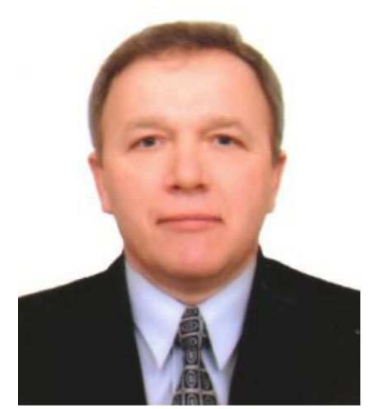

Roman Gout, Dr. Hab., Professor, Email: rgoutmollab@ukr.net

\title{
EXPRESSION OF DEFENSINS AND LIPID TRANSFER PROTEIN GENES IN SCOTS PINE SEEDLINGS INOCULATED WITH NECROTROPHIC AND HEMIBIOTROPHIC PATHOGENS
}

Fungi from the genera Fusarium, Alternaria, Botrytis and oomycete Phytophthora species cause massive dieback of seedlings in pine nurseries and orchards. The synthesis of antimicrobial compounds, including pathogenesis-related proteins, is one of the main strategies to protect juvenile plants against pathogen attack. Here, we report the data on the expression levels of lipid-transfer protein gene and four defensin genes in Scots pine (Pinus sylvestris L.) seedlings, inoculated with Alternaria alternata, Fusarium solani and Phytophthora cinnamomi during the pathological process, assessed by semiquantitative multiplex RT-PCR. We found that the expression levels of each gene greatly vary between each other and depend on the nature of the pathogen. It was detected that all tested pathogens considerably affect the expression levels of the investigated genes. A significant accumulation of PsDefl transcripts was observed in pine seedlings 48 hours after inoculation, while the expression of another PsDef4 was upregulated only during first 24 hours of contact with pathogens. The levels of PsDef 3 transcripts were elevated only in seedlings, inoculated with $F$. solani, while the expression of PSLTP1 gene was differentially regulated by all three pathogens, which indicates the dependence of transcriptional response in the seedlings on the nature of pathogen and mechanisms, which are triggered by them on the changes in signal transduction pathways. Collectively, our results suggest the involvement of defensins and lipid-transfer protein in primary defense mechanisms of Scots pine seedlings against tested pathogens.

Keywords: Pinus sylvestris L.; pathogenesis-related proteins; phytopathogenic fungi; inoculation; transcriptomic response.

\section{Introduction}

Scots pine is an ecologically and economically important forest tree species native to Eurasia. Pine stands account for $34.6 \%$ of the State Forest Fund in Ukraine, occupying about 10 million hectares (Hensiruk, 2002). In recent years, a negative dynamics has been observed in forest plantations of Ukraine, revealing a significant increase (up to $30 \%$ ) in the area of existing forest diseases clusters in all regions. Therefore, it is especially important to find ways and means to increase productivity and biological stability of pine stands in stressful environmental conditions. One of the promising ways to improve the health of pine stands is a selection of resistant genotypes by molecular markers. For this purpose, we can propose the pathogenesis-related (PR) proteins, which, due to their specificity and expression patterns, seem to be the attractive candidates (Lacerda, et al., 2014).

PR-12 family includes defensins - evolutionarily conserved molecules that are found in a broad range of organisms: from myxobacteria to mammals. Plant defensins are small $(<10 \mathrm{kD})$ basic secretory proteins characterized by amphipathic, $\beta$-layer rich structure stabilized by four or five disulfide bridges. Most of the isolated plant defensins possess activity against fungi and bacteria (Broekaert, et al., 1995). Besides antifungal and antibacterial properties, some plant defensins are able to regulate cellular enzymes and processes, including serine proteinases and $\alpha$-amylases, and $\mathrm{Ca}^{2+}$ - and $\mathrm{Na}^{+}$-channels and protein translation in vitro (Mendez, et al., 1990; 1996; Bloch \& Richardson, 1991). The genes, encoding plant defensins, are expressed constitutively in the peripheral cell layers forming the first defensive line against pathogens. In addition, the expression of plant defensins was induced by exogenous stresses, such as pathogen attack, osmotic factors, cold and drought (Lay \& Anderson, 2005).

PR-14 family is represented by lipid-transfer proteins

Цитування за ДСту: Hrunyk N. I., Kovaleva V. A., Gout R. T. Expression of defensins and lipid transfer protein genes in scots pine seedlings inoculated with necrotrophic and hemibiotrophic pathogens. Науковий вісник НЛТУ України. 2017. Вип. 27(8). С. $105-110$.

Citation APA: Hrunyk, N. I., Kovaleva, V. A., \& Gout, R. T. (2017). Expression of defensins and lipid transfer protein genes in scots pine seedlings inoculated with necrotrophic and hemibiotrophic pathogens. Scientific Bulletin of UNFU, 27(8), 105-110.

https://doi.org/10.15421/40270817 
(LTP) - small basic proteins found in all land plants, where they are encoded by large multigene families (Kader, 1996). A molecule of LTP is characterized by a compact structure made with $\alpha$-helices and eight-cysteine residue conserved motif, linked by four disulfide bridges and long C-terminal tail. This structure forms a central hydrophobic cavity, very suitable to bind hydrophobic compounds, such as lipids (Carvalho \& Gomes, 2007; Douliez, et al., 2000). LTPs are involved in key processes in plant physiology, such as cell wall organization, stabilization of membranes, signal transduction, plant growth and development (sexual reproduction, seed development, and germination) (Edstam, et al., 2013; Eklund \& Edqvist, 2003; Maldonado, et al., 2002). Beside response to abiotic stresses such as cold, drought and salinity, LTPs are also known to play a role in resistance to biotic stress (Sels, et al., 2008). Expression of LTP and defensins after infection with pathogens served the criterion for their classification as PR-proteins (García-Olmedo, et al., 1995).

The widespread and dangerous disease of coniferous seedlings is damping-off (root rot), caused by fungi from $F u$ sarium, Alternaria, Botrytis, Phytophthora genera. Depending on the lifestyle of the pathogens, they use different strategies in order to turn the processes in plant cells to their advantage and obtain the nutrients which are necessary for their existence (Horbach, et al., 2011). Biotrophic fungi as well as Oomycetes form special structures, termed haustoria, through which they receive nutrients from living cells (Mendgen \& Hahn, 2002). On the other hand, fungi leading necrotrophic lifestyle secrete toxins and enzymes that kill plant cells so that nutrients, which are released from dead tissues, are taken up by the pathogen (Horbach, et al., 2011). Moreover, hemibiotrophic fungi combine both strategies. During initial stages of infection, pathogens actively suppress the immune system of the host, which allows hyphae to spread throughout the infected plant tissue and subsequently, the toxins, secreted by a pathogen, leading to the host cells death (Koeck, et al., 2011). Young seedlings are good targets for the pathogens because the lack of powerful mechanical barriers makes them vulnerable to infection (Adomas, et al., 2007). During the host-pathogen interaction, there was observed strong overexpression or downregulation of some genes, which belong to different multigene families. Among them, the genes, coding enzymes, which are involved in the phenylpropanoid and isoprenoid pathways, fungistatic/fungicidal proteins, heatshock proteins, proteinase inhibitors and PR-proteins (Boava, et al., 2009). The last play an important role in natural defence against pathogens and pests (Hernández, et al., 2005; Veluthakkal \& Dasgupta, 2010).

Previously, we reported the purification of the two proteins, defensin and lipid-transfer protein, from pine seedlings and showed their antifungal activity (Kovaleva, et al., 2009). In addition, we have cloned the defensins genes PsDef1 (Pinus sylvestris Defensin 1) (Acc.No. EF455616.1), PsDef2 (Acc.No. EF455617.1), PsDef3 (Acc.No. JN980401.1), PsDef4 (Acc.No. KJ601732.1) and a gen of PSLTP1 (Pinus sylvestris lipid transfer protein 1) (Acc.No. JN980402.1).

In this paper, using semi-quantitative RT-PCR, we examined the transcriptional changes of PsDefl-4 and PSLTPl genes that occur in tissues after inoculation of Scots pine seedlings with dangerous pathogens: Alternaria alternata (Fr.) Keissl., Fusarium solani (Mart.) Sacc. and Phytophthora cinnamomi Rands.

\section{Material and methods}

Inoculation experiments. Seeds of Scots pine (Pinus sylvestris L.) were obtained from the Lviv forest breeding seed center (Lviv region, Ukraine). Surface-sterilized seeds were germinated on Whatman paper soaked with distilled water in Petri dishes at $26^{\circ} \mathrm{C}$ in the thermostat. 7 days after, the seedlings were used for inoculation.

The cultures of fungal pathogens $F$. solani UKM F50639, A. alternata UKM F-16752 were obtained from the D.K. Zabolotny Institute of Microbiology and Virology (Ukraine) and the culture of oomycete $P$. cinnamomi was kindly provided by the Institute of Forest Research (Poland). Microbial cultures were grown in potato dextrose broth for 7 days at $22{ }^{\circ} \mathrm{C}$ and then the mycelium was washed with sterile water and subsequently blended with an Ultra-Turrax T-25 homogenizer.

Twenty 7-day-old seedlings of $P$. sylvestris were transferred to wet, sterile Whatman paper in Petri dishes. The roots were inoculated with $1 \mathrm{ml}$ of the homogenized mycelium and covered with a layer of moist sterile filter paper. Control plants were mock-inoculated with $1 \mathrm{ml}$ sterile distilled water. The seedlings of either infected or control plants were harvested at 6,24 and 48 hours post inoculation (h.p.i.), frozen in liquid nitrogen and stored at $-70{ }^{\circ} \mathrm{C}$ until use. All the experiments were run in triplicates.

Semi-quantitative multiplex RT-PCR ( $m x P C R)$ analysis of the gene expression. Expression of PSLTP1 and PsDefl4 genes was checked using mxPCR. Total RNA was obtained using modified method of lithium chloride precipitation (Chang et al, 1993). The specific primers were designed for each gene as described previously (Shalovylo, et al., 2015; Hrunyk, et al., 2015). As a control for the reaction, we choose the housekeeping gene RPL44 (Acc.No. EL342388.1), which also was used for the calculation of the relative values of the expression level. mxPCR was run for 30 cycles in a thermal cycler using the program: $95^{\circ} \mathrm{C}$, $45 \mathrm{~s} ; 54{ }^{\circ} \mathrm{C}, 45 \mathrm{~s} ; 72{ }^{\circ} \mathrm{C}, 45 \mathrm{~s}$. The PCR products were separated by electrophoresis on a $2.0 \%$ agarose gel, visualized with ethidium bromide staining, and photographed. Densitometric analysis was made with Software GelProAnalyzed 4.0 .

\section{Result and discussion}

At the early stages of ontogenesis, pine seedlings are exposed to a variety of pathogenic invaders including bacteria, fungi and oomycetes. The last two are the causative agents of the damping-off disease in juvenile plants. Fungi from the genus Fusarium, Alternaria, Botrytis and oomycete Phytophthora are most common plant pathogens, which cause massive dieback of seedlings in pine nurseries and orchards. Since seedlings are lacking lignified tissues, they are very vulnerable to pathogen invasion. In their turn, the pathogens trigger the signal transduction cascades regulated by salicylic acid (SA), jasmonic acid (JA), and ethylene (ET), provoking changes in plant cells and, as a result, the plant accumulates the antimicrobial secondary metabolites, and transcripts of genes encoding pathogenesis-related proteins. The effectiveness of induced reactions varies, depending on the lifestyle of the invader. Responses to biotrophic pathogens are mediated largely by signal molecule SA, 
while molecules JA and ethylene modulate responses to necrotrophs. The SA- and JA/ET-signaling pathways are mostly antagonistic, but there is evidence of cross-talk between these pathways, that provides a coordinated gene regulation for effective protection against pathogens (Glazebrook, 2005).

Previously, we have shown that exogenous SA slightly increased the levels of expression of PsDefl and PsDef2 genes in pine seedlings, while in JA-treated seedlings, the amounts of transcripts of four studied defenses genes were 1.5-2 times higher than in the control (Shalovylo, et al., 2015). We assumed that pathogens with various lifestyles would differentially affect the levels of expression of PSDef1-4 genes and PSLTP1.

$F$. solani, A. alternata and $P$. cinnamomi-causative agents of wilting disease, early and late blight in higher plants, which serve the case of massive economic losses in agro-industry as well as in forestry. Two of tested pathogens belong to the ascomycetous fungi (A. alternata and $F$. solani) and one belongs to oomycetes (P. cinnamomi). Besides belonging to different kingdoms, pathogens lead different lifestyles: necrotrophic (A. alternata) and hemibiotrophic ( $F$. solani and $P$. cinnamomi) each of them use diverse mechanisms for their establishment in a host plant
(Koeck, et al., 2011). As a result, the plant responses to the infection in different ways, which we can observe in the case of examined in this manuscript pathogenic fungi.

A. alternata differently affects the expression patterns of all defensins genes (Fig. 1, A). The levels of PsDef1 and PsDef2 transcripts were increasing at 48 h.p.i. by 5.5 and 1.5 times respectively (Fig. 1, B). Expression of PsDef4 has grown rapidly during first 6 hours by 1.3 times and after 24 hours by three times. This upregulation was lessened at 48 h.p.i. by 1.2 times while comparing with control. In addition, PsDef 3 exhibits slightly reduced expression pattern at all three time points. Our findings demonstrate differential and time-coordinated expression of defensin genes in Scots pine seedlings under biotic stress caused by a necrotrophic fungus. Plant species genomes can contain a family of several defensin genes that may differentially respond to biotic stresses. In Arabidopsis thaliana, for instance, inoculation of leaves with the fungus Alternaria brassicicola results in differential expression of five defensin genes. Expression of PDF1.2 is upregulated by a fungal pathogen, while that of PDF2.2 is downregulated (Shenk, et al., 2003).
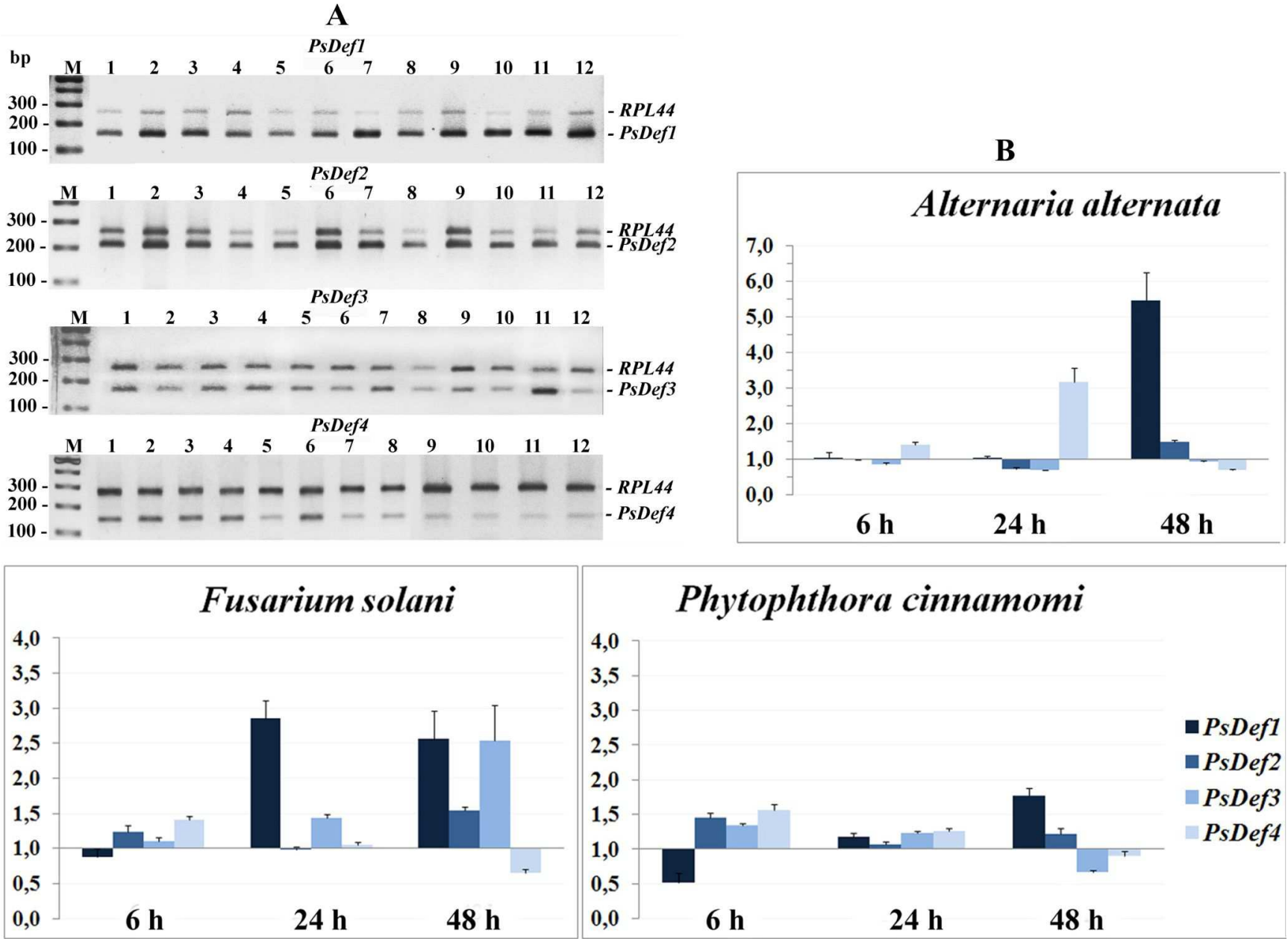

Fig. 1. Analysis of defensin gene expression in Scots pine seedlings, inoculated with phytopathogenic fungi and collected 6 hours after (1-4 lines), 24 hours after (5-8 lines) and 48 hours after (9-12 lines). A, electrophoregram of the mxPCR products obtained from RNA of pine seedlings inoculated with mycelium of $A$. alternata $(2,6,10$ lines $), F$. solani $(3,7,11$ lines) and $P$. cinnamomi $(4,8,12$ lines $)$ and noninoculated seedlings (1, 5, 9 lines). M - GeneRuler 100 bp Plus DNA Ladder (Fermentas). Right lines indicate the PCR-products: PsDef1, PsDef2, PsDef3 and PsDef4, and "house-keeping" gene RPL44. B, the diagram of the values of the expression level of PsDef1, PsDef2, PsDef3, and PsDef4 calculated relative to RPL44. The expression level of these genes in control seedlings was set to one. The values below one indicate a downregulation, while the values above one indicate an upregulation of the gene 
Both hemibiotrophic pathogens alter the expression patterns of PsDef1, PsDef2 та PsDef4 in similar way (Fig. 1, A). At 6 h.p.i., expression of PsDefl was lower than that in control sample and 24 hours after it starts to increase and 48 hours after, the levels of PsDef1 transcripts were 1.8 and 2.6 times higher in $P$. cinnamomi and $F$. solani, respectively (Fig. 1, B). Both pathogens slightly upregulate the expression of PsDef2 during the whole experiment. Expression of PsDef4, after inoculation with $F$. solani and $P$. cinnamomi, was similar to one we have observed with $A$. alternata: high levels of PsDef4 transcripts were observed only at 6 h.p.i., followed by downregulation 24 hours after and 48 h.p.i. F. solani and $P$. cinnamomi differently affect the expression of the PsDef3: in seedlings infected with Fusari$u m$, the expression of PsDef 3 was growing gradually by 1.1 times at $6 \mathrm{~h}$, and 1.4 and 2.5 times at 24 and 48 hours post inoculation, respectively. On another hand, with $P$. cinnamomi we have observed opposite result: elevated levels of $P s D e f 3$ at $6 \mathrm{~h}$ were changed with a decrease at 24 hours after and 48 h.p.i. by $10 \%$ and 1.3 times, while comparing with control.

On Figure 2, it is clearly demonstrated that PSLTP1 displays three different patterns of expression: with necrotrophic fungus, expression of PSLTP1 was higher at 6 hours after and 48 h.p.i. by 1.9 and 2.1 times, respectively, while 24 hours after it decreased by $20 \%$ compared to the control sample. We obtained the similar results while studying the changes in the expression levels of PSLTP1 transcripts during seedlings inoculation with another necrotroph - Heterobasidion annosum (Fr.) Bref. sensu lato - the causative agent of annosum root rot (Hrunyk, et al., 2013).

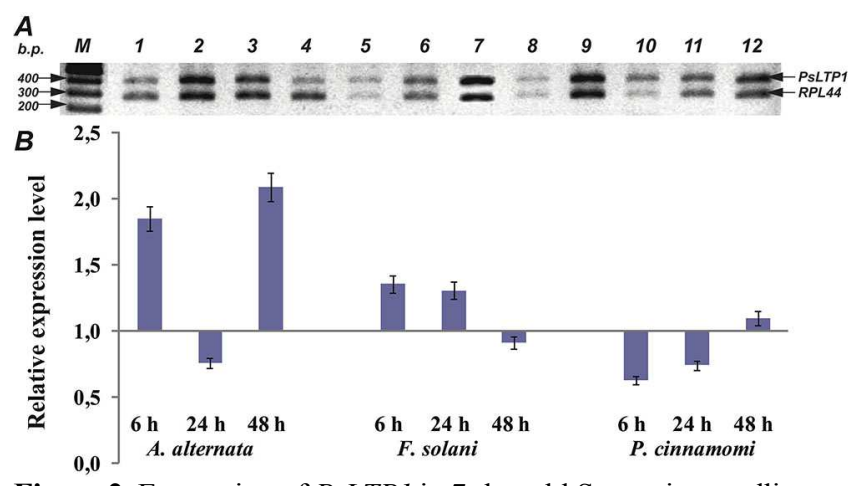

Figure 2. Expression of $P_{S L T P 1}$ in 7-day-old Scots pine seedlings. A, top panel - RT-PCR products electrophoresis obtained from RNA of seedlings, inoculated with $A$. alternata $(2,6,10), F$. solani $(3,7,11)$ and $P$. cinnamomi $(4,8,12)$ for $6(2,3,4), 24(6,7,8)$ and $48(10,11,12)$ hours after with specific primers. The expression of PSLTP in control samples sprayed with water was measured at same time points: 6 hours (1), 24 hours (5) and 48 hours (9). B, bottom panel - the diagram shows the relative expression levels. The expression level of the control was set to one. Values below one indicate a down regulation and values above one indicate an up regulation of the gene. $S \mathrm{M}-$ GeneRuler 100 bp Plus DNA Ladder (Fermentas). Right arrows indicate the PCR-products: PSLTP1 and "house-keeping" gene RPL44

Moreover, what concerns hemibiotrophic pathogens, they affect the expression of PSLTP1 in opposite to each other ways. Infection with $F$. solani leads to the lowering of PSLTP1 transcripts: 1.4 times higher expression at 6 h.p.i. was followed by dropping by 1.3 at 24 h.p.i. and $10 \%$ on the second day while comparing with the control sample. The infection of young plants by $P$. cinnamomi leads to PSLTP1 upregulation: low expression levels at 6 h.p.i. and
24 h.p.i., were slightly elevated at 48 h.p.i., relatively to the control. Gradually increase of PSLTP1 transcripts in the case with $P$. cinnamomi may be related to the nature of this pathogen, which possess specific proteins named elicitins. Those proteins are very similar to plant LTP by the ability to bind hydrophobic ligands, but unlike LTPs, elicitins exhibit sterol carrier activity. Blein and colleges proposed that during the Phytophthora-plant interaction, LTPs compete with elicitins for receptors on the plant plasma membrane (Blein, et al., 2002). As a result, those processes trigger biological responses in plant organism.

The obtained results suggest, that all tested pathogens, which belong to distinct groups and lead different lifestyles, upregulate the expression of PsDefl and PsDef2 at 48 h.p.i., the levels of transcript were more prominent for PsDefl. The infection by necrotroph increased expression of PsDef1 by 3.7 times compared to PsDef2. In addition, inoculation with hemibiotrophs showed the slightly lower difference in expression levels: for $F$. solani that value was equal to 1.7 and for $P$. cinnamomi - 1.5. It is interesting to note the opposite mode of action of necrotroph and hemibiotroph on PsDef3 expression. While A. alternata downregulates the expression, $F$. solani upregulates it during the whole experiment. It is worth mentioning that all tested pathogens induced expression of PsDef4 at 6 h.p.i. and in all cases, the levels of PsDef4 transcripts were lessened two times at 48 h.p.i. while comparing with its expression at 6 h.p.i. and much lower compared to control samples. It was previously demonstrated that PsDefl and PSLTP1 possess high activity against a broad spectrum of phytopathogenic fungi and oomycetes (Kovaleva, et al., 2009; 2011; Ermakova, et al., 2016). Therefore, upregulation of genes encoding these antifungal peptides in the vulnerable seedling tissues might assist the development of their resistance to pathogenic attacks.

\section{Conclusions}

Based on the results of the studies, we can conclude that defensins and PSLTP1 are involved into primary defense mechanisms of Scots pine against necrotrophic and hemibiotrophic pathogens. Our results suggest that these genes can serve as molecular markers for the development of the ecofriendly technologies of seedling protection against pathogenic fungi in greenhouses and nurseries. These technologies are based on the management of plant immunity, selection of resistant Scots pine genotypes and obtaining the genetically modified plants. The work in this direction in forestry is only beginning to develop.

\section{References}

Adomas, A., Heller, G., Li, G., Olson, Å, Chu, T., Osborne, J., ... Asiegbu, F. O. (2007). Transcript profiling of a conifer pathosystem: response of Pinus sylvestris root tissues to pathogen (Heterobasidion annosum) invasion. Tree Physiology, 27(10), 1441-1458. https://doi.org/10.1093/treephys/27.10.1441

Blein, J. P., Coutos-Thévenot, P., Marion, D., \& Ponchet, M. (2002). From elicitins to lipid-transfer proteins: a new insight in cell signalling involved in plant defence mechanisms. Trends in Plant Science, 7(7), 293-296. https://doi.org/10.1016/s1360-1385(02)02284-7

Bloch, C., \& Richardson, M. (1991). A new family of small (5 kDa) protein inhibitors of insect $\alpha$-amylases from seeds or sorghum (Sorghum bicolor (L) Moench) have sequence homologies with wheat $\gamma$-purothionins. FEBS Letters, 279(1), 101-104. https://doi.org/10.1016/0014-5793(91)80261-z 
Boava, L. P., Kuhn, O. J., Pascholati, S. F., Di Piero, R. M., \& Furtado, E. L. (2009). Effect of acibenzolar-S-methyl and Saccharomyces cerevisiae on the activation of Eucalyptus defences against rust. Australasian Plant Pathology, 38(6), 594-602. https://doi.org/10.1071/ap09045

Broekaert, W. F., Terras, F., Cammue, B., \& Osborn, R. W. (1995). Plant defensins: novel antimicrobial peptides as components of the host defense system. Plant Physiology, 108(4), 1353-1358. https://doi.org/10.1104/pp.108.4.1353

Carvalho, A. O., \& Gomes, V. M. (2007). Role of plant lipid transfer proteins in plant cell physiology - a concise review. Peptides, 28(5), 1144-1153. https://doi.org/10.1016/i.peptides.2007.03.004

Chang, S., Puryear, J., \& Cairney, J. (1993). A simple and efficient method for isolating RNA from pine trees. Plant Molecular Biology Reporter, 11(2), 113-116. https://doi.org/10.1007/bf02670468

Douliez, J. P., Michon, T., Elmorjani, K., \& Marion, D. (2000). Mini Review: structure, biological and technological functions of lipid transfer proteins and indolines, the major lipid binding proteins from cereal kernels. Journal of Cereal Science, 32(1), 1-20. https://doi.org/10.1006/jcrs.2000.0315

Edstam, M. M., Blomqvist, K., Eklöf, A., Wennergren, U., \& Edqvist, J. (2013). Coexpression patterns indicate that GPI-anchored nonspecific lipid transfer proteins are involved in accumulation of cuticular wax, suberin and sporopollenin. Plant Mol Biol, 83(6), 625649. https://doi.org/10.1007/s11103-013-0113-5

Eklund, D. M., \& Edqvist, J. (2003). Localization of nonspecific lipid transfer proteins correlate with programmed cell death responses during endosperm degradation in Euphorbia lagascae seedlings. Plant Physiology, 132(3), 1249-1259. https://doi.org/10.1104/pp.103.020875

Ermakova, E. A., Faizullin, D. A., Idiyatullin, B. Z., Khairutdinov, B. I., Mukhamedova, L. N., Tarasova, N. B., ... Nesmelova, I. V. (2016). Structure of Scots pine defensin 1 by spectroscopic methods and computational modeling. International Journal of Biological Macromolecules, $\quad 84, \quad 142-152 . \quad$ https://doi.org/10.1016/j.ijbiomac.2015.12.011

García-Olmedo, F., Molina, A., Segura, A., \& Moreno, M. (1995). The defensive role of nonspecific lipid-transfer proteins in plants. Trends Microbiol., 3(2), 72-74. https://doi.org/10.1016/S0966842X(00)88879-4

Hensiruk, S. A. (2002). Lisy Ukrainy [Forests of Ukraine]. Lviv: Shevchenko Scientific Society, Ukrainian State university of Forestry and Wood Technology. [in Ukrainian].

Hernández, I., Portieles, R., Chacón, O., \& Borrás-Hidalgo, O. (2005). Proteins and peptides for the control of phytopathogenic fungi. $B i$ otecnología Aplicada, 22, 256-260.

Horbach, R., Navarro-Quesada, A. R., Knogge, W., \& Deising, H. B. (2011). When and how to kill a plant cell: infection strategies of plant pathogenic fungi. $J$ Plant Physiol, 168(1), 51-62. https://doi.org/10.1016/j.jplph.2010.06.014

Hrunyk, N. I., Kovaleva, V. A., \& Gout, R. T. (2013). Osoblyvosti ekspresiyi hena lipidtransfernoho proteyinu sosny zvychaynoyi pry infikuvanni siyantsiv korenevoyu hubkoyu [Features of gene expression of a lipid-transfer protein in pine seedlings during infection by annosum root rot]. The Bulletin of Kharkiv National Agrarian University. Series Biology, 3(30), 56-60. [in Ukrainian].

Hrunyk, N. I., Yusypovych, Y. M., Kovaleva, V. A., \& Gout, R. T. (2015). Heterobasidion annosum root rot infection development in Scots pine and evaluation of the expression levels of lipid transfer protein and defensins in infected tissues. Scientific Bulletin of $U N$ $F U, 25(8), 25-32$.

Kader, J.-C. (1996). Lipid transfer proteins in plants. Annu. Rev. Plant Physiol. Plant Mol. Biol., 47, 627-654. https://doi.org/10.1146/annurev.arplant.47.1.627

Koeck, M., Hardham, A. R., \& Dodds, P. N. (2011). The role of effectors of biotrophic and hemibiotrophic fungi in infection. Cell Microbiol, 13(12), 1849-1857. https://doi.org/10.1111/j.14625822.2011.01665.x

Kovaleva, V., Kiyamova, R., Cramer, R., Krynytskyy, H., Gout, I., Filonenko, V., \& Gout, R. (2009). Purification and molecular cloning of antimicrobial peptides from Scots pine seedlings. Peptides, 30(12), 2136-2143. https://doi.org/10.1016/j.peptides.2009.08.007

Kovaleva, V., Krynytskyy, H., Gout, I., \& Gout, R. (2010). Recombinant expression, affinity purification and functional characterization of Scots pine defensin 1. Applied Microbiology and Biotechnology, 89(4), 1093-1101. https://doi.org/10.1007/s00253-010-2935-2

Lacerda, A. F., Vasconcelos, Ã A., Pelegrini, P. B., \& Grossi de Sa, M. F. (2014). Antifungal defensins and their role in plant defense. Frontiers in Microbiology, 5 . https://doi.org/10.3389/fmicb.2014.00116

Lay, F., \& Anderson, M. (2005). Defensins - components of the innate immune system in plants. Current Protein \& Peptide Science, 6(1), 85-101. https://doi.org/10.2174/1389203053027575

Maldonado, A. M., Doerner, P., Dixon, R. A., Lamb, C. J., \& Cameron, R. K. (2002). A putative lipid transfer protein involved in systemic resistance signaling in Arabidopsis. Nature, 419(6905), 399-403. https://doi.org/10.1038/nature00962

Mendgen, K., \& Hahn, M. (2002). Plant infection and the establishment of fungal biotrophy. Trends Plant Sci, 7(8), 352-356. https://doi.org/10.1016/s1360-1385(02)02297-5

Mendez, E., Moreno, A., Colilla, F., Pelaez, F., Limas, G. G., Mendez, R., ... Haro, C. (1990). Primary structure and inhibition of protein synthesis in eukaryotic cell-free system of a novel thionin, gamma-hordothionin, from barley endosperm. European Journal of Biochemistry, 194(2), 533-539. https://doi.org/10.1111/j.14321033.1990.tb15649.X

Mendez, E., Rocher, A., Calero, M., Girbes, T., Citores, L., \& Soriano, F. (1996). Primary structure of omega-hordothionin, a member of a novel family of thionins from barley endosperm, and its inhibition of protein synthesis in eukaryotic and prokaryotic cell-free systems. European Journal of Biochemistry, 239(1), 67-73. https://doi.org/10.1111/j.1432-1033.1996.0067u.x

Sels, J., Mathys, J., De Coninck, B. M. A., Cammue, B. P. A., \& De Bolle, M. F. C. (2008). Plant pathogenesis-related (PR) proteins: A focus on PR peptides. Plant Physiology and Biochemistry, 46(11), 941-950. https://doi.org/10.1016/j.plaphy.2008.06.011

Shalovylo, Y. I., Yusypovych, Y. M., Kovaleva, V. A., Gout, R. T. (2015). Vplyv fitohormoniv na ekspresiyu heniv defenzyniv sosny zvychaynoyi [The effect of phytohormones on expression of defensin gene in Scots pine]. Studia Biologica, 9(1), 15-24. [in Ukrainian].

Schenk, P. M., Kazan, K, Manners, J. M., Anderson, J. P., ... Maclean, D. J. (2003). Systemic gene expression in Arabidopsis during an incompatible interaction with Alternaria brassicicola. Plant Physiology, 132(2), 999-1010. https://doi.org/10.1104/pp.103.021683

Veluthakkal, R., \& Dasgupta, M. G. (2010). Pathogenesis-related genes and proteins in forest tree species. Tree, 24(6), 993-1006. https://doi.org/10.1007/s00468-010-0489-7

Н. І. Груник, В. А. Ковальова, Р. Т. Гут

Національний лісотехнічний університет Украӥни, м. Львів, Украйна

\section{ЕКСПРЕСІЯ ГЕНІВ ДЕФЕНЗИНІВ ТА ЛІПІДТРАНСФЕРНОГО ПРОТЕЇНУ В ПРОРОСТКАХ СОСНИ ЗВИЧАЙНОЇ, ІНОКУЛЬОВАНИХ НЕКРОТРОФНИМ І ХЕМІБІОТРОФНИМИ ПАТОГЕНАМИ}

Гриби та ооміцети родів Fusarium, Alternaria, Botrytis, Phytophthora викликають масове відмирання сіянців сосни в теплицях і розсадниках. Одною із основних стратегій захисту ювенільних рослин від патогенів $є$ синтез антимікробних сполук, зокрема, пов'язаних із патогенезом протеїнів. У цій роботі наведено дані щодо рівнів експресії чотирьох генів дефензинів та ліпідтрансферного протеїну в проростках сосни звичайної (Pinus sylvestris L.) протягом перших двох діб після їх інокуляції Alternaria alternata, Fusarium solani та Phytophthora cinnamomi. Відносну кількість транскриптів цільових генів визначали 
методом напівкількісної ПЛР зі зворотною транскрипцією. Виявлено, що досліджувані патогени змінюють рівні експресії усіх п'яти генів, а профіль експресії кожного гена залежать від природи збудника. Так, встановлено істотне збільшення транскриптів гена PsDefl у сіянцях сосни на 48 годину після інокуляції, тоді як продуктів PsDef4 - тільки протягом перших 24 годин після контакту з патогенами. 3'ясовано, що рівень експресії гена PsDef3 підвищувався тільки в проростках, які інокулювали F. solani, тоді як експресія гена PSLTPI диференційовано регулювалась всіма трьома патогенами. Загалом, результати дослідження вказують, що дефензини та ліпідтрансферний протеїн залучені у первинні реакції відповіді сосни на інфікування збудниками інфекційного вилягання сіянців

Ключові cлова: Pinus sylvestris L.; пов'язані з патогенезом протеїни; фітопатогенні гриби; інокуляція; транскриптомна відповідь.

Н. И. Груник, В. А. Ковалева, Р. Т. Гут

Национальный лесотехнический университет Украины, г. Львов, Украина

\section{ЭКСПРЕССИЯ ГЕНОВ ДЕФЕНЗИНОВ И ЛИПИДТРАНСФЕРНОГО ПРОТЕИНА В ПРОРОСТКАХ СОСНЫ ОБЫКНОВЕННОЙ, ИНОКУЛИРОВАННЫХ НЕКРОТРОФНЫМ И ХЕМИБИОТРОФНЫМИ ПАТОГЕНАМИ}

Грибы и оомицеты родов Fusarium, Alternaria, Botrytis, Phytophthora вызывают массовое отмирание сеянцев сосны в теплицах и питомниках. Одной из основных стратегий защиты ювенильных растений против патогенов является синтез антимикробных соединений, в частности, связанных с патогенезом протеинов. В этой работе приведены данные об уровнях экспрессии четырех генов дефензинов и липидтрансферного протеина в проростках сосны обыкновенной (Pinus sylvestris L.) в течение первых двух суток после их инокуляции Alternaria alternata, Fusarium solani и Phytophthora cinnamo$m i$. Относительное количество транскриптов целевых генов определяли методом полуколичественной ПЦР с обратной транскрипцией. Обнаружено, что исследуемые патогены изменяют уровни экспрессии всех пяти генов, а профиль экспрессии каждого гена зависит от природы возбудителя. Так, установлено существенное увеличение транскриптов гена PsDefl в сеянцах сосны через 48 ч после инокуляции, тогда как продуктов PsDef4 - только в течение первых 24 ч после контакта с патогенами. Выявлено, что уровень экспрессии гена $P s D e f 3$ повышался только в проростках, инокулированных $F$. solani, в то время как экспрессия гена $P S L T P 1$ дифференциально регулировалась всеми тремя патогенами. Таким образом, результаты исследования указывают на участие дефензинов и липидтрансферного протеина в первичных реакциях ответа сосны на инфицирование возбудителями инфекционного полегания сеянцев.

Ключевые слова: Pinus sylvestris L.; связанные с патогенезом протеины; фитопатогенные грибы; инокуляция; транскриптомный ответ. 